\title{
Parents as Kindergarten Teachers: The Journey to Becoming
}

\author{
Jane April Bayate Alquizola, Shara Mae Villahermosa Cabuenas, Marie Ver Bayutas Duazo, \\ Jewish Araneta Merin*
}

College of Teacher Education, Cebu Normal University, Osmeña Boulevard, Cebu City, Philippines

\section{Email address:}

jewishmerin@gmail.com (J. A. Merin),janeapril.alquizola@gmail.com(J. A. B. Alquizola),

Cabuenassharamae7@gmail.com (S. M. V. Cabuenas),duazomariever246@gmail.com (M. V. B. Duazo)

${ }^{*}$ Corresponding author

\section{To cite this article:}

Jane April Bayate Alquizola, Shara Mae Villahermosa Cabuenas, Marie Ver Bayutas Duazo, Jewish Araneta Merin. Parents as Kindergarten Teachers: The Journey to Becoming. Education Journal. Vol. 10, No. 5, 2021, pp. 166-174. doi: 10.11648/j.edu.20211005.11

Received: May 30, 2021; Accepted: September 28, 2021; Published: September 29, 2021

\begin{abstract}
The crisis has affected the education system all over the globe. Young learners were prohibited to socialize with peers and teachers which are vital to their development. Distance learning was enforced. The study was created to explore effective home-parental teaching strategies that have an impact on a child's achievements amidst pandemic. Additionally, parents' struggles encountered and teachers' perspective on how parents or guardians took the role as a Kindergarten teacher at home. Researchers' goal was to uncover the truth where parents are the light and hope in a child's education in the middle of this crisis, parent-child relationship at home. A qualitative method was used by the researchers in data gathering; instruments consisted of checklists, questionnaires, and interview questions for the parents and educators. Results revealed that teachers' emphasized parental involvement contributes a huge factor and a difference to the learners learning especially during these crucial times. Conducive home learning environment allows learners to have meaningful learning experiences. Furthermore, the use of rewards is considered the most effective home-teaching strategy by the parents/guardians before or after doing the task. Ergo, reward is a form of motivation that leads the child to cooperate to achieve a goal which results in the most effective home-teaching strategy.
\end{abstract}

Keywords: Kindergarten, Parental Engagement, Teaching Strategies, Pandemic

\section{Introduction}

It is never easy- the ride to pursuing early childhood teaching. The profession involves strenuous work and persistence in dealing with the young learners and in instilling the learning. Teachers aspire to inspire young minds and in these trying times, in the midst of a global pandemic, parents may well be the light and the best hope of the stakeholders in the educational system to at least function as motivators. The crisis has brought a drastic change to the peoples' lives and despite the inevitable reality; this is now the new normal. Economically, politically and socially citizens are slowly adapting.

In the face of challenges, safety is of utmost importance. Notwithstanding, the Department of Education has been adamant that learning "can and must continue": assuring following the conditions and safety protocols set by the Department of Health and World Health Organizations. To guarantee that DepEd still provides learning opportunities with safety, they presented the Basic Education Learning Continuity Plan (BE-LCP) [11]. Hence, to exhilarate success and deliver resourceful and innovative remote schooling, parents and teachers must work hand-in-hand.

Increased parent's engagement is essential in the students learning process and has become more crucial nowadays. In addition, all the members in the society can potentially benefit the appropriate and successful parenting program [24]. Parents and teachers sharing a responsibility to achieve such a goal is something that makes a difference [10]. Children have always looked up to their parents as their first role models and always adopt parent's values and types of behavior [22]. Thus, more worthwhile bonding and spending more family time together can be a scaffold to meaningful experience and learning. It is 
an undeniable fact that this is new to most of us: from work in the office to work-from-home, from face-to-face classes to modular learning. It may be tough for some; however, everyone is trying to catch up. It has become evident that parents have to surmise the full-time job in educating their children. And teaching and/ or motivating young learners is a different story. The passage to becoming a Kindergarten homeeducator takes a roller-coaster ride.

\subsection{Statement of the Problem}

This study aims to know the effective strategies of the parents as kindergarten teachers while on the journey to becoming. It seeks to answer the following sub problem:

1. What is the connection of the learning continuity plan to parent engagement?

2. What are the teaching practices parents applied to their child?

3. What are the advantages and disadvantages of being able to teach their children at home during pandemic?

4. What are the challenges encountered by the parents?
a. Parental capacity
b. Time
c. Money

5. What are the best home-teaching strategies have you discovered during remote learning?

\subsection{Related Studies}

From the time of the COVID-19 pandemic outbreak, people have been affected in one way or another. Countrywide lockdowns have had a strong effect on the lives of people of all professions and all ages. Various countries have implemented different learning systems, and nearly all of the parents agreed to the temporary school closure due to pandemic. The closure of the schools resulted in more responsibilities on parents' shoulders. Many teachers, families, and learners have been unprepared for this sudden shift, bringing some of the hardships and issues of increased parental involvement to the surface while engaging and trying to assist their children in various levels and types of distance learning. As a result, parents often struggle with understanding the role they should play in their children's online learning $[3,26]$. This flare-up has altered the lives and the education of at least 1.5 billion learners in 188 countries [37]. In response to the problems caused by the outbreak, the educational ministries, and other stakeholders have taken action to ensure there is still a continuity of learning.

The school is a focal point of social activity and human interaction [37]. Around the world, millions of parents have also stepped up and taken charge of their child's education. [19] argued that when parents are involved in their children's schools, academic motivation and achievement increase. Students' interest in learning, competence, and understanding of a subject area, improves and promotes student achievement. Children need the right kind of support from their parents amidst COVID-19, especially the young learners who eventually don't understand what is happening around them.
Parent engagement refers to a greater commitment and greater feeling of ownership of the action, where parents are conscious about their role as a parent [20]. From an economist's point of view, to increase educational outcomes, it is a direct effort. [5] The parent engagement is defined as a shared responsibility to actively support children's learning and development by the National Association for Family. It is beneficial to the learner and the school when the parents/ guardians are concerned about education [5]. One of the many benefits of parents being engaged with their child raises learner's achievements, selfesteem, and aspiration [39]. Also, it increases children's engagement and motivation in learning to parent's ideas and eliciting from them what they've discovered and explored with their children can develop a more authentic partnership that is both beneficial and useful to young learners. In China, online pedagogical support is provided to parents/ caregivers [2]. Spain is also offering diverse communication platforms and applications, for instance, Edugestio, in which teachers and parents' caregivers share and co-build the learning process [7]. Some countries, like Guatemala, are providing teaching guidelines and learning materials to parents/ caregivers to assure the continuation of the learning offline [6]. Equality and inclusivity are also being maintained in the education level of different countries. Governments of countries like China and South Korea are providing devices and printed assignments to those who do not have access to technology $[6,18]$.

Educators in all fields had to simultaneously confront an abrupt shift to distance/ online education while attempting to navigate the distress, grief, and upheaval caused by the global outbreak. One result of these unprecedented and disorienting circumstances was that educators mobilized to support each other [17] and parents cooperation to the school would be the best scaffold to achieve the goal or at least close to it.

\subsection{Conceptual Framework of the Study}

The Department of Education adopted modular systems similar to the other Southeast Asian countries to deliver education while prioritizing the safety of the learners [11]. Thus, DepEd implements the health protocols set by the DOH and the World Health Organization (WHO) to still continue child's learning [11]. "We have come out with a variety, with a menu of options, online is not the only answer, there's a huge debate in the Philippines on how useful or whether it is really a good way of teaching learners, so we have online, we have televisions, we have radio. If all else fails, then learning modules are being printed so that these will be delivered in various pick-up points or either parents or for the village officials to distribute to the learners," [4].

The pandemic has greatly transformed the way it is, blended learning is one of the challenges that parents with young children are facing now. Blended learning or the integration of face-to-face and online instruction [21], is widely adopted across higher education with some scholars referring to it as the "new traditional model" [32] or the "new normal" in course delivery [28]. Parents who are equipped with effective home-teaching strategies have a great impact that could help out stakeholders and policymakers to guide and secure the future. 


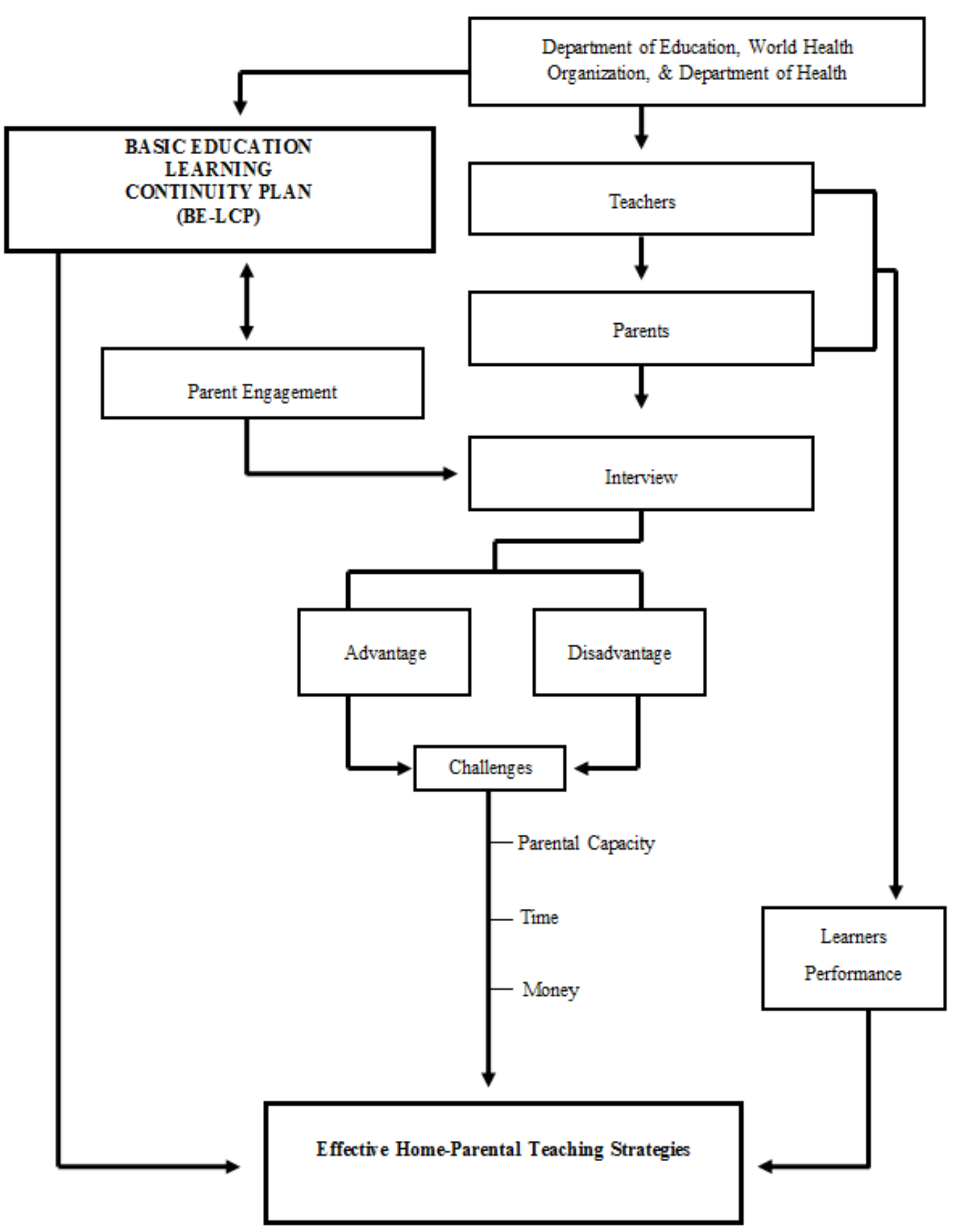

Figure 1. Conceptual Framework of the Study.

A number of investigators have assembled a comprehensive agenda of transformative and innovative research issues for blended learning that have the potential to enhance effectiveness $[16 ; 30]$. Generally, research has found that blended learning results in an improvement in student success and satisfaction, $[14 ; 13 ; 23]$ as well as an improvement in students' sense of community when comparing to face-to-face classes [33]. Those who have been most successful at blended learning initiatives stress the importance of institutional support for course redesign and planning $[25 ; 12 ; 30 ; 36]$.

Parental engagement brings a huge impact and supporting a child's education can be life-changing. All learners despite group and year level they can yield when their parents are implicated in their education. [5]. The drastic changes that we're able to experience and witness, indeed proves, change is inevitable. Working hand-in-hand in adjusting and coping these problems is one way to overcome such a crisis while still ensuring quality education and that no child will be left behind [27]. 


\section{Research Methodology}

This study uses the descriptive method using qualitative technique in gathering data as to why and how the parents' engaged their child in teaching from home using thorough interviews, open- ended questionnaires and checklists in which is used to depict results. The purpose of this study is to determine the discovered effective home-parental teaching strategies to the young learners in the time of global pandemic. The respondents of this study were the twenty- two (22) parents who have a child enrolled from the selected public and private schools in Barili, Cebu. The researchers selected parents whose children are enrolled in two private schools and one public school of the said locale. The checklist is composed of columns on the parents' journey appropriate practices as kindergarten teachers. The interview contains open ended questions about parental engagement: strategies and the challenges that parents encountered. In collecting the required data, a qualitative method was used. A letter of request, questionnaires and checklist were prepared and sent to the professor for validation. The researchers then forward the letter of approval to the respective respondents through face-to-face and/or online. The conducting of the checklist and in-depth interview was done from their respective houses or the chosen area by the parents. The researchers clarified some terms to the respondents for the respondents to answer the question with full knowledge of the respondents' responsibility as the subject of the study and answer them with all honesty. After collecting the data, the results were interpreted and analyzed then came to the conclusion and the recommendation of the study.

\section{Analysis and Interpretation of Results}

\subsection{Parents}

To achieve the aim of the study, the researchers' asked parents to have a glimpse of their journey as a teacher to their child at home. The descriptive questions were provided and then the parents' responses were analyzed by using thematic analysis under three themes in the following section: learning progress, struggles, and parental teaching techniques.

Table 1. Parents' way in tracking the learners' progress.

\begin{tabular}{lll}
\hline As a parent, how do you know that the child is learning? & Frequency & Percentage \\
\hline Learning Progress & 22 & 100 \\
Question and answer- oral and written & 22 & 100 \\
\hline
\end{tabular}

\subsubsection{Learning Progress}

Before the pandemic, in school, teachers had different ways of assessing the learners' learning progress. And to know ways to assess and to improve it is essential in increasing the learners' learning. [1] Children's needs to be assessed in order for both the parents and the teachers to know if they are learning or if how they are taught are effective. Also, if there are any interventions needed especially now during remote learning.

Question and Answer-Oral and Written

A parent once said “wa gyud ko'y lain mahimo ma'am, mangutana ra gyud tawn ko niya para makahibaw ko kug nakat-on ba gyud siya or kong pananglitan, sa akong day off ma'am, og wala na kaayo'y buhaton sa balay, magpa answeranswer ko niya ug ginagmay kutob sa akong nahibaw-an intawn". For most of the parents, working and stay-atparents, there was no other way for them to assess if the child is learning except to ask them orally or ask the learner to write as what they instructed them to do. Or for instance, those who hired tutors, parents ask the teachers on their progress or look at outputs if there are any.

Table 2. Parents' struggles while teaching at home.

\begin{tabular}{lll}
\hline What are the challenges encountered by you while teaching at home? & Frequency & Percentage \\
\hline Struggles & 22 & 100 \\
Unmotivated Learner & 11 & 50 \\
Balancing Responsibilities & 11 & 50 \\
\hline
\end{tabular}

\subsubsection{Struggles}

According to the respondents, they find remote learning a struggle since it used to depend on school where they send and fetch their child from and to the school. And the unexpected event has increased work pressure for parents. [34]

\section{(i). Unmotivated Learner}

"Ma, kapuya na oy", a parent expressed her frustrations that this is what her child usually tells her whenever it is already time to answer the module. The fact that parents only rely on modules as the child's learning material, they find it more challenging. The lack of social interaction [15] and parent as the teacher contributed to the learner having the lack of motivation.

\section{(ii). Balancing Responsibilities}

A parent shared that she couldn't focus on two things at the same time: work and the child's remote learning. Sometimes, it is already stressful at work and the parent needs to rest but she has to attend to the child's needs as well which needs more patience. A parent said that it is more of her priority to find food to put on the table. "At times, mangayo ko og tabang sa iyang maguwang, tabangan man sad hinoon siya kaso lang malooy sad ko ba kay nag labad pod na iyahang ulo sa iyang module mismo nya ako pod, di man sad mahimo og muhunong ko ug trabaho, wa sad mi kan-on." 
Table 3. Parents' best home- teaching strategies.

\begin{tabular}{lll}
\hline What is/are the effective strategy that you have discovered in teaching your child at home? & Frequency & Percentage \\
\hline Parental Teaching Techniques & 22 & 100 \\
Rewards & 15 & 68.18 \\
Hired a tutor & 3 & 13.64 \\
Independent Learning & 4 & 18.18 \\
\hline
\end{tabular}

\subsubsection{Parental Teaching Techniques}

Researchers consider parents to be as one of the sole hopes in these trying times since it is still uncertain when we are going back to normal or if this is already the "new normal". Knowing these, researchers believe that it can create a huge impact to the stakeholders especially to the learner.

\section{(i). Rewards}

For a guardian, teaching their child remotely is extra work due to the struggles encountered. If a learner is unmotivated it is tough for their academic achievement to improve [38]. Parents have found giving rewards to the child, may it be on before, during or after the answering of the module works. It may be a form of pleasure time to play, food treats, and/ or toys. For them, the child seems to obey if there is something good in return. The giving of rewards to motivate the students let them exert effort for the promised rewards. [38]

\section{(ii). Hired a Tutor}

Some respondents are single parents, some are working parents, and some don't think they are not equipped in teaching their child, so for them, hiring a tutor would be the best for both of them: parent and child. One of the single parents, a father, shared that it was tougher for the parent during the remote learning, he explained, "Nagkoha nalang gyod ko og tutor para niya ma'am kay mabiyaan man ang bata sa klase niya ang ako lang gyod kayod lang gyod ko ug maayo para mangita og extra bayad sa tutor".

\section{(iii). Independent Learning}

There were a few or 4 out of the 22 respondents proudly expressed that they don't force their child to answer the module but instead their children are the ones who initiate and enjoy answering the module with or without their assistance. "Grateful rasad kaayo ko aning bataa ma'am kay siya gyud mismo manghagad nako ma'am ba na mag answer mi nya uska adlaw ra na niya mahuman ang module ma'am. Pariha karon ma'am oh, magda naman jud ko sa module inig uli nako sa balay run, di gyud na niya lum-an ug dili mahuman ma'am", a parent proudly shares to the researchers.

\subsection{Teachers}

To aid parents' responses, the researchers asked teachers with open-ended questions about their struggles, viewpoints, and suggestions while working amidst pandemic. Teachers' responses were scrutinized using thematic analysis methodologies and the results were grouped into the following five themes: Struggles to Adapt, Sentiments, Accessibility, Validity, Connections, and Voices: take into considerations. These five themes are explained below after every table.

Table 4. The transition faced by the educators.

\begin{tabular}{lll}
\hline How do you find the work from home set up? & Frequency & Percentage \\
\hline Struggles to Adapt & 6 & 100 \\
Too many Distractions at home & 3 & 50 \\
High demands from the school & 2 & 33.3 \\
Adjustments from face-to-face to remote learning & 1 & 16.7 \\
\hline
\end{tabular}

\subsubsection{Struggles to Adapt}

Work from home set-up has its advantages and disadvantages to private sectors. Institutions and educational systems made special efforts to help those students whose parents are unsupportive and whose home environments are not conducive to study [9]. From the data gathered, it shows their struggles in adapting the new normal setting in education. Researchers noted three definite struggles: Too many Distractions at home, High demands from the school and Adjustments from face-to-face to remote learning.

\section{(i). Too Many Distractions at Home}

To focus on working at home with distractions was a common struggle among the teachers. Three out of six respondents had trouble completing their tasks at home. Two participants stated their endeavor working at home, "One advantage is that we don't need to catch up with the time and the disadvantage is that we cannot focus on our work because of the distraction like our children" and "cannot focus on my job because of the distraction like our home chores, my child's noise.", T1 and T2.

\section{(ii). High Demands from the School}

A high demand from the school gives teachers more load that lead to one of the struggles to adapt." At first, it's hard to adjust because I am used to face to face but eventually I can manage. The demands from the Department of Education were too high like modules should not be photocopied or back to back." and "Very challenging, by giving different kinds of modalities like online, modular and blended (tutorial type of learning)", T4 and T6.

\section{(iii). Adjustments from Face-to-Face to Remote Learning}

The last in the list under struggles to adapt was the teacher's adjustments from face-to-face to remote learning. Kindergarten 
teachers were adjusting to this what we called "new normal" because they were used to the face-to-face setup but eventually, step by step, little by little, they were able to manage it. One respondent mentioned about her adjustments from the ability to observe her learners to ask the progress from parents. "We have shifting schedules and at home, I still allocate some time to make modules for my learners. Embracing it by not quitting, despite having less knowledge in technology", T5.

Table 5. Teachers' point of view.

\begin{tabular}{lll}
\hline How does learning differ between the normal and new normal? & Frequency & Percentage \\
\hline Sentiments & 8 & 100 \\
Home and school relatiosnhip & 5 & 62.50 \\
Determine child's ability & 3 & 37.5 \\
\hline
\end{tabular}

\subsubsection{Sentiments}

This is defined as the teacher's point of view about the "normal" and "new normal" education. Educators said that there is really a big difference between these two in education. One principal said, "Teachers have gone into problem-solving mode. They want their kids to be safe, they want their kids to be well and they want their kids to learn as well" [31]. There are two distinct sentiments: Home-school relationships and determining a child's ability.

\section{(i). Home-School Relationship}

In this crisis, the home-school relationship is vital to achieve a goal; parents and educators partnership to still give quality education to the learners. Five respondents reported that there was learner-teacher interaction in a "normal" education while learner-guardian in "new normal" set up. "In normal class there is an interaction between a student and a teacher and especially the pupils are engaged in physical activities than the new normal", according to T6 and "Normal learning, learners learn in school with the teacher, new normal, learners learn at home with their guardians", T1.

\section{(ii). Determine Child's Ability}

There are many techniques and tools that a teacher can use in evaluating a child's performance or ability inside the classroom. In this crisis, even educators were not ready, particularly, learners' homeschooling. The researchers found out that in this school year, almost all teachers have not seen their enrollees personally. Teachers shared their viewpoints on this, T3, "In new normal education I am only relying on the outputs of the learners not sure who answers or makes it. I can't distinguish who among my learners needs remediation" and "In teaching it is very difficult to tell the child's ability when there is no face to face", T4.

Table 6. Teachers' struggles amidst pandemic.

\begin{tabular}{lll}
\hline What are the common challenges that you encounter? & Frequency \\
\hline Accessibility & 7 & Percentage \\
Lack of resources for the modules- internet connection, gadgets, bond paper, printer. & 5 \\
Knowledge about new things & 2 & 71.4 \\
\hline
\end{tabular}

Table 7. Equating performances.

\begin{tabular}{lll}
\hline Aside from test scores, is there any way you can say if the child is learning? & Frequency \\
\hline Validity & 6 \\
Child's progress at home & 3 \\
Video performance tasked & 2 \\
Class observation & 100 \\
\hline
\end{tabular}

\subsubsection{Accessibility}

In this identified theme, these barriers prevent teachers to be fully equipped in this sudden transition in education. The Internet for Filipinos is perceived to be beneficial in many aspects as it helps them to find information as a learning tool for their research and school activities [29]. Common concerns that teachers encounter are the subthemes: Lack of resources for the modules- internet connection, gadgets, bond paper, printer, and etc., and knowledge about new things.

\section{(i). Lack of Resources for the Modules: Internet Connection, Gadgets, Bond Paper and Printer}

The most common barrier shared by the teachers was the lack of resources for the modules- internet connection, gadgets, bond paper, printer, and etc. Teachers shared the following: T1, "Materials we use in printing the modules",
T2, "Common challenges that we encounter is the materials we use in printing", T3, "The common challenges that I encounter, the materials used in printing and poor internet connection especially if we have webinar", T4, "DepEd's proposal were amazing, however, it can't be applicable when it can be applied internet and gadgets alike are needed. It is more applicable if it's already face to face", T6, "Latency of network for online classes."

\section{(ii). Knowledge About New Things}

Challenges open a new door to learn new things, to improve you and what you usually do. There are many things to know if you are eager to go outside the box. Teacher 5 shared her challenges that she experienced, "I find it less challenging because I was a nursery teacher, so I was kind of used to it, especially in making their modules because I have 
some references but I can't deny that there are new things I encountered and I am learning it".

\subsubsection{Validity}

Test scores are a way to find out if the child is learning but as what we experienced this time, teachers were unsure if the child answered it. Under this theme are the three sub themes namely; Child's progress at home, Video performance tasked, and Class observation.

\section{(i). Child's Progress at Home}

In this set-up, parents become the eyes and ears of the teachers where they communicate about the child's progress. Before, a child's performance inside the classroom is the parent's happiness, knowing that their child is done well in class. Now, parents' reports about their child's performance at home are the teacher's way to evaluate such progress. "Kindergartens don't have examinations, but we can identify their learning through asking parents about the progress of their child", T1.

\section{(ii). Video Performance Tasked}

At first, teachers had a hard time validating if learners are the one's answering the modules and are learning from it. Educators found ways to at least have a glimpse on how parents teach their child and how these young children learn, by utilizing their gadgets, Respondents uttered, "It's hard to tell because some parents are the one answering the modules (based on the hand writing). Some strategies I did are letting the parents take a video of their child while mentioning the letters and numbers", T4 and "Yes, through video performance tasked", T6.

\section{(iii). Class Observation}

There are schools that have adapted blended learning classes. Class observation is another way to evaluate the child's performance or abilities. "During review, my learners are participating during discussion and if there is a student that can't answer, I go back for him/her to catch up", T5.

Table 8. Educators' Perspective towards Parental Involvement.

\begin{tabular}{lll}
\hline How important is parent engagement? & Frequency & Percentage \\
\hline Connections & 6 & 100 \\
Parent-teacher cooperation & 4 & 66.7 \\
Parent-child relationship & 2 & 33.3 \\
\hline
\end{tabular}

\subsubsection{Connections}

Researchers noted this theme as "connections". All teachers said that parent engagement is really important especially nowadays. In education, an important year for the young learners where the foundation should be strong, basic skills and other things should be developed in order to go to the next level. It was reported that parent-child interactions, specifically stimulating and responsive parenting practices, are important influences on a child's academic development [35, 8]. Two sub themes were identified by the researchers; Parent-teacher cooperation and Parent-child relationship.

\section{(i). Parent-Teacher Cooperation}

Collaborations is necessary to achieve a specific goal especially in this trying times where the learners stayed at home to learn and at the same time to be safe These are some respondents who mentioned about the parent- teacher collaboration amidst pandemic; T3, "Very important because from them, we know the development of the child. Parents are always our partner in educating and molding young learners, especially in our situation today" and "It is very important because they are the one who acts as a teacher when the teacher is not around especially those pupils who choose modular learning type of modality”, T6.

\section{(ii). Parent-Child Relationship}

Parent- child relationship is also important as parentteacher partnership, parent and child's bond could lead to the wholesome development of a child, the guide and the provider to the child's needs and wants. Two teachers shared about parent-child connections, "They are the one who guide the learner in answering modules", T1 and "Very important especially in Kindergarten, we need the guardians because they are the one who guide the learner in answering the modules", $\mathrm{T} 2$.

Table 9. Educators' desideratum to improve the system.

\begin{tabular}{lcc}
\hline $\begin{array}{l}\text { What can you recommend to the Department of Education that contributes to the } \\
\text { effectiveness of the quality of education amidst pandemic? }\end{array}$ & Frequency \\
\hline Voices: take into considerations & 6 \\
Vis-à-vis classes & 1 & 100 \\
Technology hardware and internet quality availability & 4 & 16.7 \\
Engaging strategies or proposals & 66.6 & 1 \\
\hline
\end{tabular}

\subsubsection{Voices: Take into Considerations}

The six identified themes are Voices: take into considerations. Educators wanted to be heard by the Department of Education to give what they expected.
However, teachers mentioned that they provide some educational needs but it is not enough. Researchers noted three subthemes, Vis-à-vis classes, Technology hardware and internet quality availability, and Engaging strategies or proposals. 


\section{(i). Vis-à-vis Classes}

During the pandemic, schools went shut down for a while, until the government loosened the restrictions. Teachers were able to go to school but still no pupils inside the school premises. One respondent said," Face to face class", T2. There's a reason behind this statement, aside from they were used to face-to-face classes, and she wanted to give the best education to the children. Without them inside the class, teacher 2 can't figure out every child's ability.

\section{(ii). Technology Hardware and Internet Quality Availability}

Teachers requested for devices and internet availability due to high demands of their institution. They were being provided by these things but it was not enough, they even got money from their own pockets just to meet the needs like printing those modules, buying loads to access the internet, particularly when there is a webinar to attend to. One of the respondents shared what are the things needed during time, "Provide enough supplies for the printing of the modules, gadget for the teachers and learners for online class and stable internet connection, more seminars/webinars for the teachers in using technology", T3.

\section{(iii). Engaging Strategies or Proposals}

One private teacher noted the recommendation to have an effective and quality education to come up with strategies, "As a private teacher they should not freeze the education, instead, they should teach the pupils on how to engage the new normal learning", T6.

\section{Conclusion}

To mitigate the mental and physical health consequences, the government, schools of both public and private institutions, parents, and policymakers must provide a structure through utilizing regular routines, communication, and developing new partnerships. Studies show parentteacher collaboration is essential to the child's learning development. Based on the findings, teachers' emphasized parental involvement contributes a huge factor and a difference to the learners learning especially during these crucial times. They have realized that learner's dependency on their parents wherein oftentimes the parents were the ones answering the given learning modalities instead of the child, will not do any good to their child. Thus, teachers come up with different and varied strategies to capture their child's interest like letting them send a short video of the child doing the assigned task from time to time would somehow help. Despite guardians' struggles to strive for excellence and quality education they still managed to explore new strategies on how to teach and handle their children's remote learning. Moreover, findings have shown that rewarding their child was considered the most effective teaching home strategy. Children are said to easily obey when there is a reward. Rewards may be in a form of playtime, food treat or toys which parents think that even it is given before, during or after, it still works.

\section{Recommendation}

The researchers discovered how parents or guardians deal and came up with different techniques to provide the education to their child at home. Thus, the following recommendations are hereby presented: During the new normal, parents and teachers hope to have face-to-face classes at least twice a week to attain quality education, To have learning materials such as a laptop and/ or tablet to be used by both the teachers and parents, Research to explore the impact of a child's education having learning materials such as laptop and/ or tablet to be used, In-depth exploration of blended learning activity, Discover more about teachers' challenges in dealing with the home versus school works amidst crisis, Parents should realize that parental involvement is a huge factor to the growth of the child, hence, it should be applied, and A large number of respondents identified giving rewards to their child as motivation. As a parent in the future, using rewards and praising words to boost the child's interest would make a great difference in the growth of the child: mentally, socially and intellectually.

\section{References}

[1] Acar-Erdol, T., Yildizli, H. (2018). Classroom Assessment Practices of Teachers in Turkey. https://eric.ed.gov/?id=EJ1183343

[2] Bhamani, S., et al. (2020). Home Learning in Times of Covid: Experiences of Parents. Journal of Education and Educational Development, $\quad 7 \quad$ (1). http://dx.doi.org/10.22555/joeed.v7i1.3260

[3] Boulton, H. (2008). Managing e-Learning: What are the real implications for schools? The Electronic Journal of ELearning, 6 (1), 11-18.

[4] Briones, L. M. 2020, June 19. GOVPH. https://www.deped.gov.ph/2020/06/24/briones-educationministers-unite-to-ensure-learning-continuity-amid-covid-19/

[5] Cape, M. G., et al. (2016). Parental Involvement on Pupils' Performance Epstein's Framework. The Online Journal of New Horizons in Education. Volume 6, Issue 4. https://classroom.google.com/u/2/c/MjY1OTc0ODQ2MjM0/ $\mathrm{m} / \mathrm{Mjc0MzczNDU} 4 \mathrm{MDI} 4 /$ details

[6] Chang, G. C., \& Yano, S. (2020). How are countries addressing the COVID-19 challenges in education? A snapshot of policy measures. Retrieved from World Education Blog:

https://gemreportunesco.wordpress.com/2020/03/24/how-arecountries addressing-the-covid-19-challenges-in-education-asnapshot-of-policy-measures/

[7] Chircop, D. (2020). Education in isolation in the pandemic, following the path of Isaac Newton. https://www.europarl.europa.eu/thinktank/en/document.html?r eference=EPRS_BRI(2020)651940

[8] Committee on Early Childhood Pedagogy. (2000). Eager to learn: Educating our preschoolers. The National Academies Press. 
[9] Daniel, S. J. (2020). Education and the COVID-19 pandemic. Prospects 49. 91-96. https://doi.org/10.1007/s11125-020-09464-3

[10] Delgado, P. (2019, October 22). The Importance of Parental Involvement in Teaching. Observatory of Education Innovation. $\quad$ https:/observatory.tec.mx/edu-news/theimportance-of-parental-involvement-in-teaching

[11] Department of Education. (2020, May 05). Official Statement. https://www.deped.gov.ph/2020/05/06/official-statement-2/

[12] Dringus, L. P., and A. B. Seagull. 2015. A five-year study of sustaining blended learning initiatives to enhance academic engagement in computer and information sciences campus courses. In Blended learning: Research perspectives. Vol. 2. Edited by A. G. Picciano, C. D. Dziuban, and C. R. Graham, 122-140.

[13] Dziuban, C., Hartman, J., Cavanagh, T., \& Moskal, P. (2011). Blended courses as drivers of institutional transformation. In A. Kitchenham (Ed.), Blended learning across disciplines: Models for implementation, (pp. 17-37).

[14] Dziuban, C., \& Moskal, P. (2011). A course is a course is a course: Factor invariance in student evaluation of online, blended and face-to-face learning environments. The Internet and Higher Education, 14 (4), 236-241.

[15] Garbe, A., et, al. (2020). COVID-19 and Remote Learning: Experiences of Parents with Children during the Pandemic. American Journal of Qualitative Research. Vol. 4. 45-65. https://doi.org/10.29333/ajqr/8471

[16] Garrison, D. R., \& Kanuka, H. (2004). Blended learning: Uncovering its transformative potential in higher education. The Internet and Higher Education, 7, 95-105.

[17] Gerbrant, J. et al. (2020). From Despair to Hope: A Narrative Journey to Becoming Amateur Intellectuals During COVID19. Journal of Digital Life and Learning. Vol 1 No, 1, 1-15. https://ojs.scholarsportal.info/ontariotechu/index.php/dll/articl e/download/115/48/

[18] Giannini, S., \& Lewis, S. G. (2020). Three ways to plan for equity during the coronavirus school closures. Retrieved from https:/gemreportunesco.wordpress.com/2020/03/ 25/three-waysto-plan-for-equity-during-the-coronavirus-school-closures/

[19] Gonzalez-DeHass, A. R., Willems, P. P., \& Holbein, D. M. F. (2005). Examining the relationship between parental involvement and student motivation. Educational Psychology Review, 17 (2), 99-123. doi: 10.1007/s10648-005- 3949-7.

[20] Goodall, Janet \& Montgomery, Caroline. (2014) Parental involvement to parental engagement: a continuum. Educational Review, 66: 4, 399-410, DOI: 10.1080/00131911.2013.781576.

[21] Graham, C. R. (2013). Emerging practice and research in blended learning. In M. G. Moore (Ed.), Handbook of distance education, (3rd ed., pp. 333-350).

[22] Kasapi, Gjylymsere, (2013), Pedagogjia familjare, Shkup, pp. 82.

[23] Means, B., Toyama, Y., Murphy, R., \& Baki, M. (2013). The effectiveness of online and blended learning: A meta-analysis of the empirical literature. Teachers College Record, 115 (3), 1-47.

[24] Merin, J., (2018). Practical Review and Evaluation on Parenting Education. International Journal of Evaluation and Research in Education. V. 7 I 3. 253-258. https://www.researchgate.net/publication/332546937_Practica 1_Review_and_Evaluation_on_Parenting_Education
[25] Moskal, P., Dziuban, C., \& Hartman, J. (2013). Blended learning: A dangerous idea? The Internet and Higher Education, 18, 15-23.

[26] Murphy, E., \& Rodríguez-Manzanares, M. A. (2009). Teachers' perspectives on motivation in high school distance education. Journal of Distance Education, 23 (3), 1-24.

[27] No Child Left Behind Act of 2001, P. L. 107-110, 20 U.S.C. § 6319 (2002).

[28] Norberg, A., Dziuban, C. D., \& Moskal, P. D. (2011). A timebased blended learning model. On the Horizon, 19 (3), 207216. https://doi.org/10.1108/10748121111163913.

[29] Nuncio, R. (2019). The State of Youth Internet Studies in the Philippines: Implications for Future Research and Policy Studies. Researchgate.net. https://www.researchgate.net/profile/Rhoderick-

Nuncio/publication/334849078 The State_of_Youth_Internet Studies in the Philippines Implications for Future Resear ch and Policy Studies/links/5d43537d299bf1995b5e $5 \mathrm{c} 21 / \mathrm{Th}$ e-State-of-Youth-Internet-Studies-in-the-PhilippinesImplications-for-Future-Research-and-Policy-Studies.pdf

[30] Picciano, A. G. (2009). Blending with purpose: The multimodal model. Journal of Asynchronous Learning Networks, 13 (1), 7-18.

[31] RNZ. (2020). COVID-19 coronavirus: Teachers respond to the challenge of online learning. https://www.nzherald.co.nz/nz/news/article.cfm?c_id=1\&obje ctid $=12319666$

[32] Ross, B., \& Gage, K. (2006). Global perspectives on blended learning: Insight from WebCT and our customers in higher education. In C. J. Bonk, \& C. R. Graham (Eds.), Handbook of blended learning: Global perspectives, local designs, (pp. 155-168).

[33] Rovai, A. P., \& Jordan, H. M. (2004). Blended learning and sense of community: A comparative analysis with traditional and fully online graduate courses. International Review of Research in Open and Distance Learning, 5 (2), 1-13.

[34] Sowparnika, P. K. A. (2021). Connected to devices, disconnected from children: struggles of urban, dual-earning parents in India during COVID-19. DOI: https://doi.org/10.1080/17482798.2020.1859396

[35] Topor, D., et al. (2010). Parent Involvement and Student Academic Performance: A Multiple Mediational Analysis. Journal of Prevention \& Intervention in the Community. 183197. https://doi/full/10.1080/10852352.2010.486297

[36] Tynan, B., Ryan, Y., \& Lamont-Mills, A. (2015). Examining workload models in online and blended teaching. British Journal of Educational Technology, 46 (1), 5-15.

[37] UNESCO. 2020, April 04. UNESCO.ORG. https://en.unesco.org/news/13-billion-learners-are-stillaffected-school-university-closures-educational-institutions

[38] Usher, A., et. al. (2012). Student Motivation-An Overlooked Piece of School Reform. Center on Education Policy. https://files.eric.ed.gov/fulltext/ED532666.pdf

[39] Wairimu, J., et al. (2016). Analysis of Parental Involvement and Self-Esteem On Secondary School Students In Kieni West Sub-County, Nyeri County, Kenya. Journal of Education and $\begin{array}{llll}\text { Practice. } & \text { Vol. } & 7, & \end{array}$ https://files.eric.ed.gov/fulltext/EJ1115884.pdf 